\title{
Assessment of Undiscovered Oil and Gas Resources of the East Coast Mesozoic Basins of the Piedmont, Blue Ridge Thrust Belt, Atlantic Coastal Plain, and New England Provinces, 2011
}

\section{Introduction}

During the early opening of the Atlantic Ocean in the Mesozoic Era, numerous extensional basins formed along the eastern margin of the North American continent from Florida northward to New England and parts of adjacent Canada. The basins extend generally from the offshore Atlantic continental margin westward beneath the Atlantic Coastal Plain to the Appalachian Mountains. Using a geology-based assessment method, the U.S. Geological Survey (USGS) estimated a mean undiscovered natural gas resource of 3,860 billion cubic feet and a mean undiscovered natural gas liquids resource of 135 million barrels in continuous accumulations within five of the East Coast Mesozoic basins (fig. 1; table 1): the Deep River, Dan River-Danville, and Richmond basins, which are within the Piedmont Province of North Carolina and Virginia; the Taylorsville basin, which is almost entirely within the Atlantic Coastal Plain Province of Virginia and Maryland; and the southern part of the Newark basin (herein referred to as the South Newark basin), which is within the Blue Ridge Thrust Belt Province of New Jersey (fig. 1). The provinces, which contain these extensional basins, extend across parts of Georgia, South Carolina, North Carolina, Virginia, Maryland, Delaware, Pennsylvania, New Jersey, New York, Connecticut, and Massachusetts (fig. 1).

The basins formed along the continental margin in response to the regional uplift, extension (rifting), and crustal thinning that occurred during the early opening of the Atlantic Ocean in middle Carnian (Late Triassic) time, approximately 227 million years ago. The basins were filled with a variety of sediments as they formed, including boulder beds, coarse-grained fluvial to deltaic sandstones, red siltstones, mudstones, gray and black shales, and coal. These deposits represent the diverse fluvial to deltaic and lacustrine environments that existed within the basins. The rifting ended early in the Jurassic with the onset of regional volcanism and intrusion of diabase dikes and sills.

\section{Source Rocks}

The source rocks for oil and gas within the Mesozoic basins include the gray and black shales and the coal beds. The shales accumulated in nearshore deltas, in interdistributary bays, and in the deeper portions of the lakes that

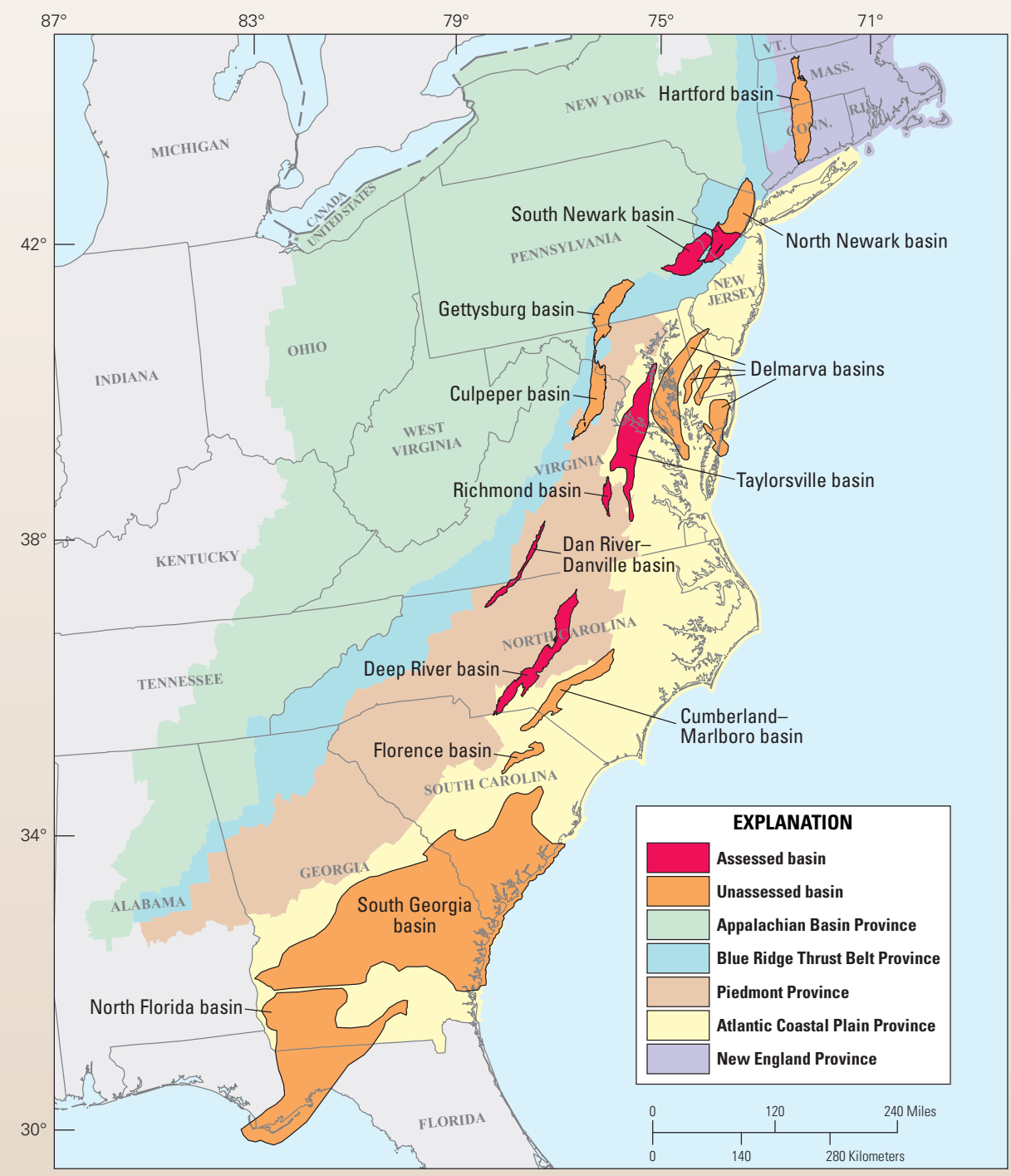

Figure 1. Map of the Eastern United States showing the locations of the five quantitatively (volumetrically) assessed East Coast Mesozoic basins, the nine basins that were not volumetrically assessed, and the U.S. Geological Survey province boundaries. Each basin includes one continuous gas assessment unit (tables 1, 2). 
Table 1. East Coast Mesozoic basin assessment results.

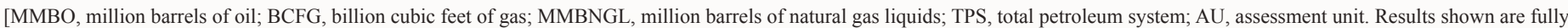

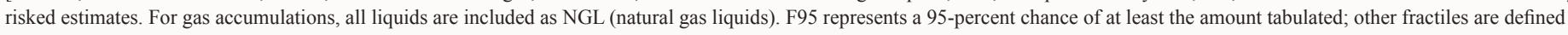
similarly. Fractiles are additive under the assumption of perfect positive correlation. Gray shading indicates not applicable]

\begin{tabular}{|c|c|c|c|c|c|c|c|c|c|c|c|c|c|}
\hline \multirow{3}{*}{$\begin{array}{l}\text { Total Petroleum System (TPS) } \\
\text { and Assessment Unit (AU) }\end{array}$} & \multirow{3}{*}{$\begin{array}{l}\text { Field } \\
\text { type }\end{array}$} & \multicolumn{12}{|c|}{ Total undiscovered resources } \\
\hline & & \multicolumn{4}{|c|}{ Oil (MMBO) } & \multicolumn{4}{|c|}{ Gas (BCFG) } & \multicolumn{4}{|c|}{ NGL (MMBNGL) } \\
\hline & & F95 & F50 & F5 & Mean & $F 95$ & F50 & F5 & Mean & F95 & F50 & $F 5$ & Mean \\
\hline \multicolumn{14}{|l|}{ Taylorsville Basin Composite TPS } \\
\hline $\begin{array}{l}\text { Taylorsville Basin Continuous } \\
\text { Gas AU }\end{array}$ & Gas & & & & & 516 & 985 & 1,880 & 1,064 & 16 & 34 & 71 & 37 \\
\hline \multicolumn{14}{|l|}{ Richmond Basin Composite TPS } \\
\hline $\begin{array}{l}\text { Richmond Basin Continuous } \\
\text { Gas AU }\end{array}$ & Gas & & & & & 99 & 194 & 382 & 211 & 4 & 10 & 20 & 11 \\
\hline \multicolumn{14}{|l|}{ Newark Basin Composite TPS } \\
\hline $\begin{array}{l}\text { South Newark Basin Continuous } \\
\text { Gas AU }\end{array}$ & Gas & & & & & 363 & 785 & 1,698 & 876 & 1 & 4 & 10 & 4 \\
\hline \multicolumn{14}{|l|}{ Deep River Basin Composite TPS } \\
\hline $\begin{array}{l}\text { Deep River Basin Continuous } \\
\text { Gas AU }\end{array}$ & Gas & & & & & 779 & 1,527 & 2,990 & 1,660 & 35 & 75 & 158 & 83 \\
\hline \multicolumn{14}{|c|}{ Dan River-Danville Basin Composite TPS } \\
\hline $\begin{array}{c}\text { Dan River-Danville Basin } \\
\text { Continuous Gas AU }\end{array}$ & Gas & & & & & 17 & 42 & 106 & 49 & 0 & 0 & 1 & 0 \\
\hline Total continuous resources & & & & & & 1,774 & 3,533 & 7,056 & 3,860 & 56 & 123 & 260 & 135 \\
\hline
\end{tabular}

occupied the basins. The majority of the coal accumulated in marshes and swamps that developed around the basin margins early in the depositional history of the basins. In addition, smaller amounts of coal accumulated locally within the overlying deltaic deposits. Black shale beds may range in thickness from a few feet to several hundred feet. Kerogen in these beds generally consists of material derived from vascular plants and algae, which are the types of kerogen that are prone to yield both gas and oil. With respect to the generation of liquid hydrocarbons, the thermal maturation values of the source rocks range widely from basin to basin, from within the zone of dry gas to immature. The potential reservoirs in these basins are continuous accumulations that encompass a variety of lithologies ranging from boulder conglomerates and very coarse sandstones to mudstone, shale, and coal. The shale beds that are interbedded with coarser grained strata may act effectively as seals.

\section{Resource Summary}

The assessment of the East Coast Mesozoic basins is based on the geologic and geochemical characteristics of the individual total petroleum systems (TPS) that were recognized within the basins. For the petroleum source rock, the characteristics include the source rock richness, thermal maturation, timing of petroleum generation, and migration; for the reservoir rocks and seals, they include their stratigraphic position and content and petrophysical properties. Using this geologic framework, the USGS defined a composite TPS and an assessment unit (AU) for continuous accumulations in each of the 14 major East Coast Mesozoic rift basins. The basins are present both onshore and offshore (in Stateadministered waters) of the Eastern United States (fig. 1). The USGS quantitatively assessed the technically recoverable, undiscovered resources within five of the total petroleum systems and associated assessment units that demonstrated the most potential for generating and accumulating hydrocarbons (fig. 1; tables 1,2). Several assessment units appear to contain continuous accumulations of gas, within both the shale and coal source rocks and within the adjacent coarser grained, siliciclastic strata. Small amounts of oil and petroliferous hydrocarbons, such as asphalt, have been detected in some of the wells drilled in these basins.

For the total of the continuous resources, the USGS estimated a mean of 3,860 billion cubic feet of gas and a mean of 135 million barrels of natural gas liquids (table 1). The available data indicate that, of the five basins that were quantitatively assessed, the Deep River, Taylorsville, and South Newark basins appear to possess the potential to produce the most hydrocarbons (table 1).

\section{For Further Information}

More information about the East Coast Mesozoic basins and the assessment methodology, as well as other oil and gas assessments, total petroleum systems, and assessment units may be found at this USGS Web site: http://energy.usgs.gov.
Table 2. East Coast Mesozoic basins with probable total petroleum systems that were not quantitatively assessed, showing type of total petroleum system and assessment unit.

\begin{tabular}{lcc}
\multicolumn{1}{c}{ Basin } & $\begin{array}{c}\text { Type of total } \\
\text { petroleum } \\
\text { system }\end{array}$ & $\begin{array}{c}\text { Type of } \\
\text { assessment } \\
\text { unit }\end{array}$ \\
\hline $\begin{array}{c}\text { Hartford } \\
\text { North Newark } \\
\text { (northern half of } \\
\text { Newark basin) } \\
\text { Gettysburg }\end{array}$ & $\begin{array}{c}\text { Composite } \\
\text { Composite }\end{array}$ & $\begin{array}{c}\text { Continuous gas } \\
\text { Continuous gas }\end{array}$ \\
$\begin{array}{l}\text { Culpeper } \\
\text { Delmarva (basins) }\end{array}$ & Composite & Continuous gas \\
Cumberland- & Composite & Continuous gas \\
$\quad$ Marlboro & Continuous gas \\
Florence & Continuous gas \\
South Georgia & Composite & Continuous gas \\
North Florida & Composite & Continuous gas \\
\hline
\end{tabular}

\section{East Coast Mesozoic Basin Assessment Team}

Robert C. Milici (rmilici@usgs.gov), James L. Coleman, Elisabeth L. Rowan, Troy A. Cook, Ronald R. Charpentier, Mark A. Kirschbaum, Timothy R. Klett, Richard M. Pollastro, and Christopher J. Schenk.

\section{Acknowledgments}

The East Coast Mesozoic Basin Assessment Team acknowledges the Directors and staff of the State geological surveys of North Carolina, Virginia, Pennsylvania, and New Jersey for providing geological information and assisting with the basin-analysis workshops, which were held in preparation for the assessment. 